\title{
Anterior sternoclavicular dislocation in Villaret's syndrome
}

\author{
Raghavendra Chalikwar, Dhaval Shukla \\ Department of Neurosurgery, National Institute of Mental Health and Neurosciences, Bengaluru, Karnataka, India
}

A 46-year-old lady presented with recurrent glomus jugulare tumor. She underwent surgery in 2009 and developed lower cranial nerve palsy. The neurological examination at present revealed paralysis of right $7^{\text {th }}-12^{\text {th }}$ cranial nerves (Villaret's syndrome). The general examination revealed anterior sternoclavicular dislocation on right with drooping of the right shoulder [Figure 1a]. A chest radiograph confirmed the clinical finding [Figure 1b]. A magnetic resonance imaging of the brain revealed a large craniocervical glomus jugulare tumor [Figure 1c].

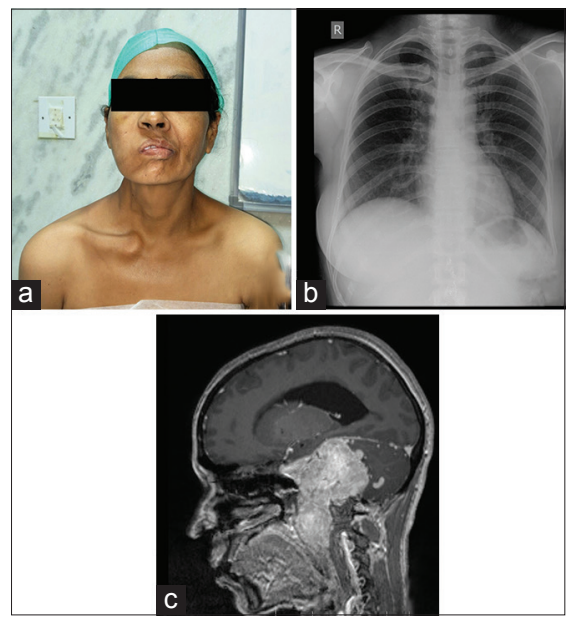

Figure 1: (a) Clinical photograph revealing anterior sternoclavicular dislocation on the right. (b) Chest radiograph showing an increase in sternoclavicular joint space with dislocation or right. (c) Magnetic resonance imaging showing large craniocervical glomus jugulare tumor

\section{Address for correspondence:}

Dr. Dhaval Shukla, Department of Neurosurgery,

National Institute of Mental Health and Neurosciences,

Bengaluru - 560 029, Karnataka, India.

E-mail: neurodhaval@rediffmail.com

\begin{tabular}{|l|l|}
\hline \multicolumn{2}{|c|}{ Access this article online } \\
\hline Quick Response Code: & Website: \\
\hline & www.ruralneuropractice.com \\
\cline { 2 - 2 } & \\
\hline
\end{tabular}

The clinical signs of IX nerve palsy are due to paralysis of sternocleidomastoid and trapezius muscles. The sternocleidomastoid is tested by having the patient rotate the head to opposite side against resistance while the examiner notes the muscle's contraction by inspection and palpation. The trapezius is tested by having the patient shrug the shoulders against resistance, and comparing the two sides by observation and palpation. ${ }^{[1]}$ Besides demonstration of the weakness of muscles, other signs of IX nerve palsy include shoulder girdle depression, limited active coronal plane abduction, scapular dyskinesis, and scapular flip sign. ${ }^{[2]}$

The sternoclavicular dislocation is rarely caused due to IX nerve palsy. The IX nerve palsy results in shoulder ptosis due to the loss of the trapezius muscle support, which increases stresses transmitted across the medial clavicular head and sternoclavivular joint resulting in early degenerative changes. These degenerative changes progress to arthritis or hypertrophy, later resulting in anterior sternoclavivular dislocation. ${ }^{[3,4]}$

\section{Declaration of patient consent}

The authors certify that they have obtained all appropriate patient consent forms. In the form the patient(s) has/have given his/her/their consent for his/her/their images and other clinical information to be reported in the journal. The patients understand that their names and initials will not be published and due efforts will be made to conceal their identity, but anonymity cannot be guaranteed.

\section{Financial support and sponsorship Nil.}

This is an open access article distributed under the terms of the Creative Commons Attribution-NonCommercial-ShareAlike 3.0 License, which allows others to remix, tweak, and build upon the work non-commercially, as long as the author is credited and the new creations are licensed under the identical terms.

For reprints contact: reprints@medknow.com

How to cite this article: Chalikwar R, Shukla D. Anterior sternoclavicular dislocation in Villaret's syndrome. J Neurosci Rural Pract 2016;7:308-9. 


\section{Conflicts of interest}

There are no conflicts of interest.

\section{References}

1. Brazis PW, Masdeu JC, Biller J, editors. Cranial nerve XI (The Spinal Accessory Nerve). In: Localization in Clinical Neurology. $5^{\text {th }}$ ed., Ch. 13. Philadelphia: LWW; 2007. p. 369-76.
2. Kelley MJ, Kane TE, Leggin BG. Spinal accessory nerve palsy: Associated signs and symptoms. J Orthop Sports Phys Ther 2008;38:78-86.

3. Athwal GS. Sternoclavicular joint disorders. In: Berry DJ, Steinmann SP, Tornetta $P 3^{\text {rd }}$, Einhorn TA, editors. Adult Reconstruction (Orthopedic Surgery Essential Series). Philadelphia: LWW; 2007. p. 220-5.

4. Piazza C, Cappiello J, Nicolai P. Sternoclavicular joint hypertrophy after neck dissection and upper trapezius myocutaneous flap transposition. Otolaryngol Head Neck Surg 2002;126:193-4. 